\title{
Effects of Hyalobarrier gel and Seprafilm in preventing peritendinous adhesions following crush-type injury in a rat model
}

\author{
당 Emel Yurdakul Sıkar, M.D., 1 ำ Hasan Ediz Sıkar, M.D., ${ }^{2}$ \\ (1) Hüsamettin Top, M.D., ${ }^{3}$ 이 Ahmet Cemal Aygıt, M.D., ${ }^{1}$
}

\begin{abstract}
1Department of Plastic, Reconstructive and Aesthetic Surgery, Bağcılar Training and Research Hospital, İstanbul-Turkey ${ }^{2}$ Department of General Surgery, Kartal Dr. Lütfi Kirdar Training and Research Hospital, İstanbul-Turkey ${ }^{3}$ Department of Plastic, Reconstructive and Aesthetic Surgery, Trakya University Faculty of Medicine, Edirne-Turkey
\end{abstract}

\begin{abstract}
BACKGROUND: In the present study, the aim was to evaluate the effects of Hyalobarrier gel (Anika Therapeutics S.r.l., Abano Terme, Italy) and Seprafilm adhesion barrier (Genzyme Corporation, Cambridge, MA, USA) in the prevention of peritendinous adhesions following a crush-type injury.

METHODS: Twenty five female Wistar Albino rats, weighing 230 to $270 \mathrm{~g}$ and 7 to 9 months of age were randomized into 5 groups. Group I was the control group, Group 2 comprised the Hyalobarrier gel group, Group 3 was made up of the Seprafilm-treated subjects, Group 4 was the tendon repair and Hyalobarrier gel group, and Group 5 was the tendon repair and Seprafilm group. Two gastrocnemius muscle tendons of each animal, a total of 50 tendons, were used. The animals were sacrificed with the administration of a high dose of anesthetic on postoperative day 40. Macroscopic evaluation of adhesions was classified by 2 blinded researchers according to Tang's adhesion grading system. The number of fibroblasts and the density and formation of collagen fibers were noted for histopathological examination.
\end{abstract}

RESULTS: None of the subjects in Group 2 was determined to have a severe adhesion, and moderate or severe adhesions were detected in Groups 3, 4, and 5. There was no statistically significant difference between Group 2 and the control group ( $p=0.737$ ). Groups 3, 4, and 5 demonstrated fewer adhesions than Groups I and $2(p<0.05)$. Groups 4 and 5 had fewer adhesions than Groups 2 and $3(p<0.05)$. There was no statistically significant difference between Groups 4 and $3(p=0.342)$. The histopathological findings were consistent with the macroscopic findings.

CONCLUSION: Seprafilm was found to be effective in the prevention of peritendinous adhesions following a crush-type injury with or without repair of the tendon fibers. In contrast, Hyalobarrier gel was found to be effective only following repair of the tendon fibers.

Keywords: Hyaluronic acid; Seprafilm; surgical adhesions; tendon injuries.

\section{INTRODUCTION}

Peritendinous adhesions are the major cause of morbidity after tendon repair. Much better results are obtained due to a true clinical evaluation, atraumatic surgical techniques, a wellplanned surgical procedure, and early mobilization after surgical treatment. ${ }^{[1-3]}$ Various agents have been used to prevent adhesions. $^{[4-14]} \mathrm{A}$ crush-type injury is the most common injury after lacerations. ${ }^{[15]}$ Although the adhesions after the laceration repair were evaluated in most of the studies, adhesions developed after surgical treatment of a tendon crush injury are a more common problem than lacerations.

Hyaluronic acid is found as sodium hyaluronate in connective tissues of the human body and has been reported as effective in decreasing the scar formation. Carboxymethyl cellulose or

Cite this article as: Yurdakul Sıkar E, Sıkar HE, Top H, Aygıt AC. Effects of Hyalobarrier gel and Seprafilm in preventing peritendinous adhesions following crush-type injury in a rat model. Ulus Travma Acil Cerrahi Derg 2019;25:93-98.

Address for correspondence: Hasan Ediz Sıkar, M.D.

Kartal Dr. Lütfi Kırdar Eğitim ve Araştırma Hastanesi, Genel Cerrahi Kliniği, İstanbul, Turkey

Tel: +90 216 - 44I 3900 E-mail: hasan.sikar@me.com 
cellulose gum is used as a vector in drug and food industries. The Seprafilm adhesion barrier (Genzyme Corporation, Cambridge, MA, USA) is a bioresorbable membrane composed of sodium hyaluronate and carboxymethyl cellulose. It is used in abdominal and thoracic surgery. ${ }^{[16-18]}$ Seprafilm forms a barrier and separate damaged tissues till the healing process for 7 days in the abdomen. Seprafilm was found to be successful after repair of tendons due to laceration. ${ }^{[4-6]}$ The Hyalobarrier gel (Anika Therapeutics S.r.l, Abano Terme, Italy) is a highly viscous gel of an autocross-linked derivative of hyaluronic acid. It has a similar mechanism to prevent adhesions in the abdomen. The aim of this study was to evaluate the efficacy of Seprafilm and Hyalobarrier gel for adhesions after tendon crush injuries with or without repair.

\section{MATERIALS AND METHODS}

This present study was conducted in the Trakya University Experimental Animals Unit and approved by the Trakya University Animal Experiments Local Ethics Committee (08/009). Twenty-five Wistar albino female rats weighing $250 \pm 20$ gr and 7-9 months old were bred in the experimental animals unit. Two gastrocnemius muscle tendons of each animal and a total of 50 tendons were used. There were five groups, each including five animals, which were randomized. The animals were kept in five cages under satisfactory environmental pathogen-free conditions, a 12-hour day/night cycle at room temperature, with a free access to water and a normal diet.

The five groups consisting of five rats each and ten tendons were formed as follows: Group I, control group; Group 2, Hyalobarrier gel group; Group 3, Seprafilm group; Group 4, tendon repair and Hyalobarrier gel group; Group 5, tendon repair and Seprafilm group (Table I).

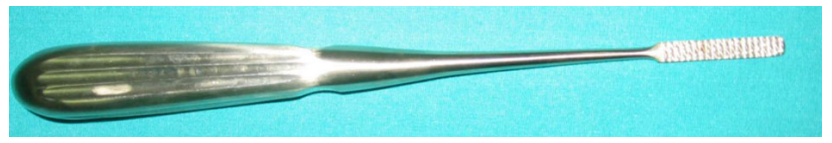

Figure 1. The rasp used to create the crush-type injury.
Table I. Properties of groups

Group I A crush-type injury was created in the tendon.

Group 2 A crush-type injury was created in the tendon, and $15 \mathrm{mg} / \mathrm{ml}$ Hyalobarrier gel was applied.

Group 3 A crush-type injury was created in the tendon, and IxI cm of Seprafilm was wrapped.

Group 4 A crush-type injury was created in the tendon; tendon fibers were repaired with a stitch, and $15 \mathrm{mg} / \mathrm{ml}$ Hyalobarrier gel was applied.

Group 5 A crush-type injury was created in the tendon; tendon fibers were repaired with a stitch, and $|x| \mathrm{cm}$ of Seprafilm was wrapped.

All animals were anesthetized with $10 \mathrm{mg} / \mathrm{kg}$ ketamine hydrochloride (Ketasol, Richter Pharma Ag, Wels, Austria) first and $5 \mathrm{mg} / \mathrm{kg}$ xylazine (Rompun, Bayer Turk Kimya San. Ltd. Sti., Istanbul, Turkiye) after 5 minutes, intramuscularly. A rasp weighing 47 grams with a $1 \mathrm{~mm}$ thread spacing and length was used to create a crush injury (Fig. I). The threaded surface of the rasp was $3 \mathrm{~cm}$ in height and $0.5 \mathrm{~cm}$ in width.

\section{Operational Technique}

Rats were placed in the supine position, and a longitudinal skin incision of $\mathrm{I} \mathrm{cm}$ was made for both the left and right posterior extremity. The gastrocnemius muscle tendon was reached, and the tendon sheath was excised following blunt dissection of subcutaneous tissues. The same surgeon created the crush injury in the middle third of the tendon (Fig. 2). The same rasp was used for sliding on over the gastrocnemius tendon 20 times with a pressure of its own weight.

The crush injury was created in Group I (control group). 15 $\mathrm{mg} / \mathrm{ml}$ Hyalobarrier gel was applied on the tendon with its own injector following the crush injury in Group 2. In Group 3 , Seprafilm IxI cm was prepared and wrapped over the ten-
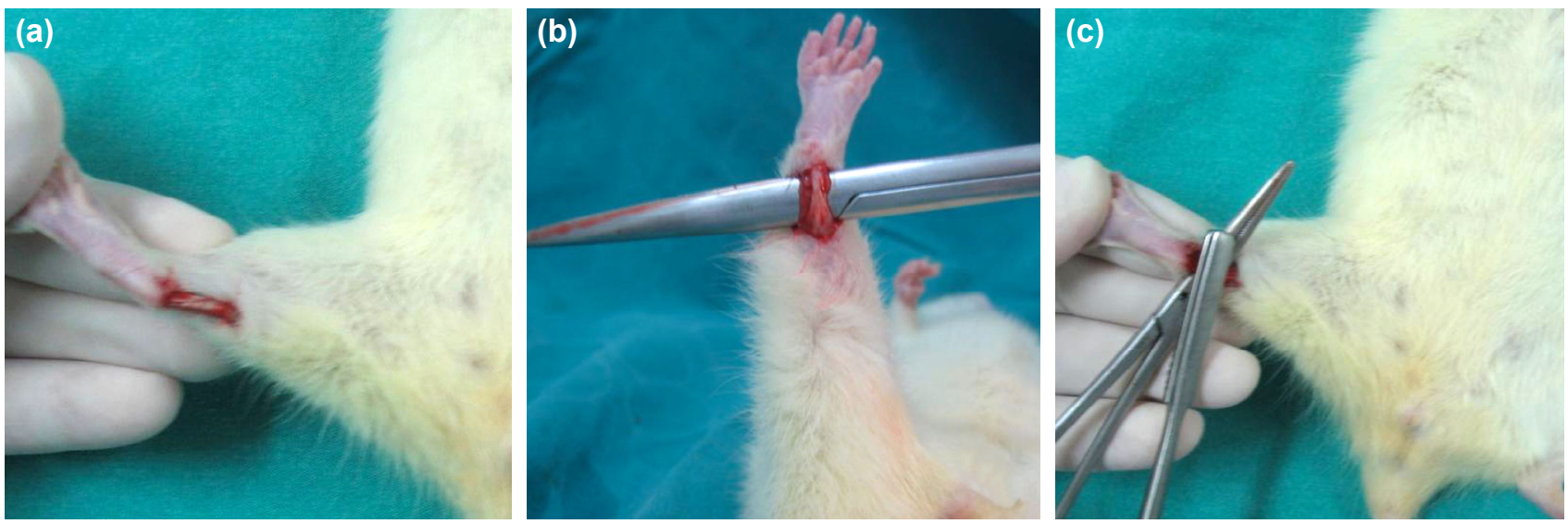

Figure 2. Operational technique. Gastrocnemius muscle tendon of the rat (a). Tendon, after excision of the tendon sheath (b). Creating the crush-type injury by sliding on over tendon (c). Tendon following the crush-type injury (d). 

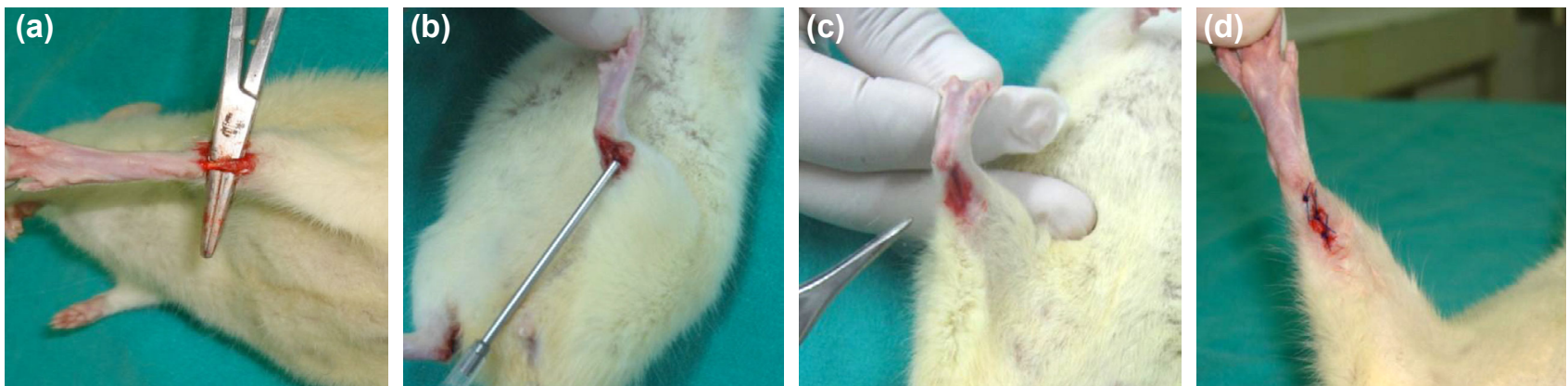

Figure 3. Application of Hyalobarrier gel and Seprafilm. Repair of tendon fibers in Groups 3 and 5 (a). Application of Hyalobarrier gel (b). Application of Seprafilm (c). Closure of the skin (d).

don following the crush injury. In Group 4, ruptured tendon fibers were sutured with $5 / 0$ polypropylene, and $15 \mathrm{mg} / \mathrm{ml}$ Hyalobarrier gel was applied over the tendon with its own injector following the crush injury. Finally, ruptured tendon fibers were sutured with 5/0 polypropylene, and Seprafilm $|x| \mathrm{cm}$ was wrapped over the tendon following the crush injury in Group 5 (Fig. 3).

Immobilization was not applied after surgery. Tendon rupture was not observed during the follow-up period. Animals were sacrificed using a high dose of anesthetic on the postoperative Day 40. A previous incision was used for the macroscopic evaluation of adhesions. The tendon was excised with an untouched section of $0.2 \mathrm{~cm}$ from the proximal and distal part following a macroscopic evaluation.

\section{Macroscopic Evaluation}

Two blind surgeons evaluated 50 gastrocnemius tendons. Adhesions were scored according to Tang et al. ${ }^{[19]}$ classification that has been used before (Table 2). The density, mobility, and

Table 2. Adhesion grading system defined by Tang et al.

\begin{tabular}{ll}
\hline Points & Features of adhesions \\
\hline 0 & Quantity \\
\hline & No apparent adhesions \\
2 & Localized, longitudinal extension within $10 \mathrm{~mm}$ \\
3 & Longitudinal extension between 10 and $15 \mathrm{~mm}$ \\
& Extensive, longitudinal extension beyond $15 \mathrm{~mm}$ \\
1 & Quality \\
2 & No apparent adhesions \\
3 & Loose, elastic, and largely movable \\
& Moderately, dense, and movable \\
0 & Dense, rigid, and not movable \\
2 & Grading of adhesions \\
3.4 & No adhesions \\
5.6 & Slight adhesions \\
\hline
\end{tabular}

length of adhesions was noted. Adhesion grade of each tendon was revealed by the sum of quantity and quality features.

\section{Histopathological Evaluation}

Histopathological evaluation of the adhesions was performed by a blind investigator. All specimens were fixed in a $10 \%$ formalin solution. Serial sections of $3 \mu \mathrm{m}$ following a routine tissue processing were taken and stained with hematoxylin and eosin. The thinnest and the finest sections of the cellular area were found for all tissues, and fibroblasts were counted in the five lens fields at 100x magnification. The mean number of fibroblasts per field was calculated for each tendon. Also, the density and formation of collagen fibers were scored as follows: "+" for mild and irregular collagenosis, "++" for moderate collagenosis, "+++" for dense and regular collagenosis.

A statistical analysis was carried out using the Statistical Package for Social Sciences software (SPSS Inc. version 13.0, Chicago, IL, USA). Overall comparisons of the groups were done using the Kruskal-Wallis test for macroscopic evaluation and density and formation of collagen. Paired comparisons of the groups were done by the Mann-Whitney $U$ test. The Kolmogorov-Smirnov test was used to evaluate normality of the distribution for the number of fibroblasts; also, the Dunn test was used for group comparisons. Numeric values were represented as $n$ (number of rats), mean \pm standard deviation.

\section{RESULTS}

Hyalobarrier gel and Seprafilm were not observed during the dissection in the experimental groups. The adhesion scores related to groups are shown in Table 3. There were no animals with severe adhesion in Group 2, and moderate or severe adhesion in Groups 3, 4, and 5 were detected. There was no statistically significant difference between Group 2 and the control group ( $p=0.737$ ). Groups 3, 4, and 5 showed fewer adhesions than Groups I and $2(p<0.05)$. Groups 4 and 5 had fewer adhesions than Groups 2 and 3, respectively $(p<0.05)$. There was no statistically significant difference between Groups 4 and 3 $(p=0.342)$. The macroscopic findings are presented in Figure 4 .

Histopathological findings were parallel with macroscopic findings (Table 4). The number of fibroblasts was decreased 

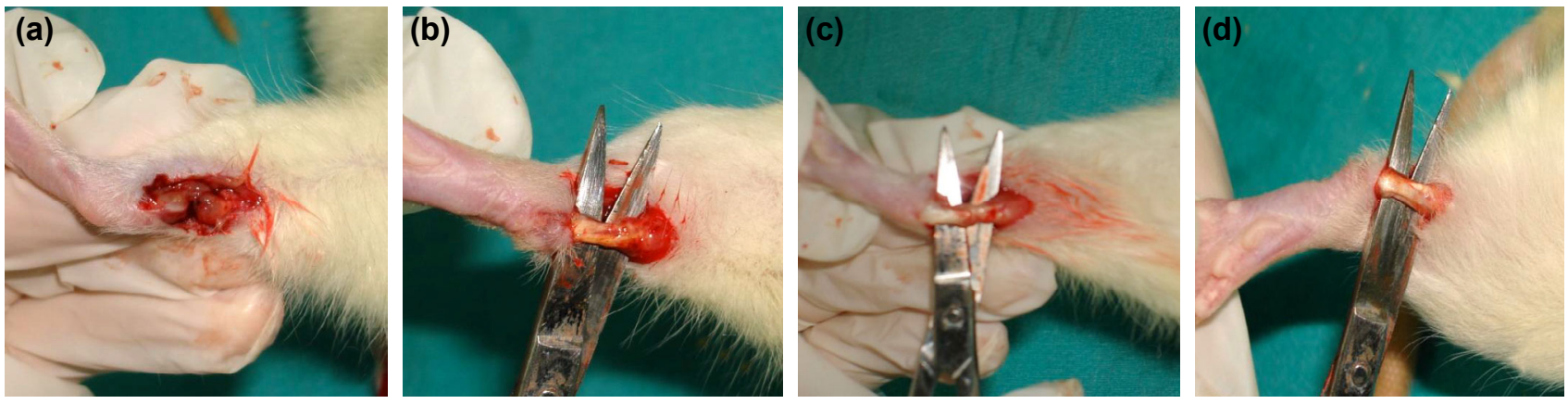

Figure 4. Macroscopic findings. Severe adhesions (a). Moderate adhesions. (b) Slight adhesions (c). No adhesions (d).
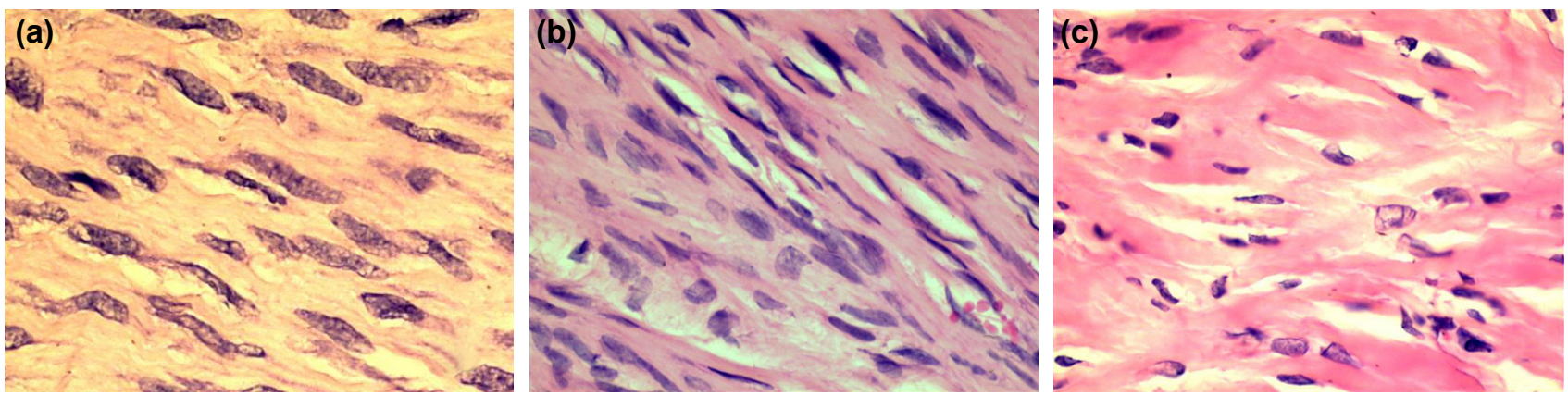

Figure 5. Histological findings (hematoxylin and eosin staining, magnification x400). Mild and irregular collagen structure (a). Moderate collagen structure (b). Dense and regular collagen structure (c).

in Groups 2, 3,4 and 5, respectively $(p<0.05)$. Groups 4 and 5 had better results than other groups $(p<0.05)$, and Group 5 has shown the lowest number of fibroblasts $(p<0.001)$.

Table 3. Macroscopic evaluation of adhesions

\begin{tabular}{|c|c|c|c|c|c|c|c|c|}
\hline \multirow[t]{2}{*}{ Adhesions } & \multicolumn{2}{|c|}{ None } & \multicolumn{2}{|c|}{ Slight } & \multicolumn{2}{|c|}{ Moderate } & \multicolumn{2}{|c|}{ Severe } \\
\hline & $n$ & $\%$ & $n$ & $\%$ & $\mathbf{n}$ & $\%$ & $\mathbf{n}$ & $\%$ \\
\hline Group I & & & 6 & 12 & 2 & 4 & 2 & 4 \\
\hline Group 2 & & & 4 & 8 & 6 & 12 & & \\
\hline Group 3 & 2 & 4 & 8 & 16 & & & & \\
\hline Group 4 & 4 & 8 & 6 & 12 & & & & \\
\hline Group 5 & 8 & 16 & 2 & 4 & & & & \\
\hline Total & 14 & 28 & 26 & 52 & 8 & 16 & 2 & 4 \\
\hline
\end{tabular}

Table 4. Histopathological evaluation
Groups 4 and 5 had a better formation and density of collagen fibers than Groups 1 and $2(p<0.05)$. There was no statistically significant difference between Groups I, 2, and 3. Histopathological findings are shown in Figure 5. A statistical comparison of the adhesion degrees between the groups is shown in Table 5.

\section{DISCUSSION}

The fingers and hands are the anatomic sites that are most frequently injured at work. Crush-type injuries constitute up to $10 \%$ when a single-type injury occurs. Multiple-type injuries cause a proportional increase of up to $13 \% .^{[15]}$ The restoration of functions following tendon repair is one of the aims of hand surgery. Although the improvements in tendon repair and postoperative rehabilitation have had a positive impact on healing, adhesions after hand surgery remain

Number of fibroblasts (mean \pm SD)

Density and formation of collagen fibers ( $n / \%)$

\begin{tabular}{lllll} 
& & + & ++ & +++ \\
\hline Group 1 & $71.4 \pm 2.2$ & $4 / 8 \%$ & $6 / 12 \%$ & $6 / 12 \%$ \\
Group 2 & $73.0 \pm 5.4$ & $4 / 8 \%$ & $6 / 12 \%$ & $1 / 2 \%$ \\
Group 3 & $67.6 \pm 3.3$ & $3 / 6 \%$ & $6 / 12 \%$ & $3 / 6 \%$ \\
Group 4 & $62.0 \pm 3.7$ & $1 / 2 \%$ & $5 / 10 \%$ & $4 / 8 \%$ \\
Group 5 & $49.9 \pm 2.0$ & $1 / 2 \%$ & + & \\
\hline
\end{tabular}

SD: Standard deviation. 
Table 5. Statistical comparison of adhesion degrees between the groups

\begin{tabular}{lccc}
\hline Groups & Macroscopic evaluation & Number of fibroblasts & Density and formation of collagen fibers \\
\hline Group 1 - Group 2 & $\mathrm{p}=0.737$ & $\mathrm{p}=1.0$ & $\mathrm{p}=1.0$ \\
Group 1 - Group 3 & $\mathrm{p}=0.015$ & $\mathrm{p}=0.233$ & $\mathrm{p}=0.483$ \\
Group 1 - Group 4 & $\mathrm{p}=0.006$ & $\mathrm{p}<0.001$ & $\mathrm{p}=0.038$ \\
Group 1 - Group 5 & $\mathrm{p}<0.001$ & $\mathrm{p}<0.001$ & $\mathrm{p}=0.024$ \\
Group 2 - Group 3 & $\mathrm{p}=0.003$ & $\mathrm{p}=0.017$ & $\mathrm{p}=0.483$ \\
Group 2 - Group 4 & $\mathrm{p}=0.002$ & $\mathrm{p}<0.001$ & $\mathrm{p}=0.038$ \\
Group 2 - Group 5 & $\mathrm{p}<0.001$ & $\mathrm{p}<0.001$ & $\mathrm{p}=0.024$ \\
Group 3 - Group 4 & $\mathrm{p}=0.342$ & $\mathrm{p}=0.01$ & $\mathrm{p}=0.168$ \\
Group 3 - Group 5 & $\mathrm{p}=0.009$ & $\mathrm{p}<0.001$ & $\mathrm{p}=0.102$ \\
Group 4 - Group 5 & $\mathrm{p}=0.075$ & $\mathrm{p}<0.001$ & $\mathrm{p}=0.702$ \\
\hline
\end{tabular}

a major obstacle against healing. ${ }^{[4-6]}$ Adhesions can prevent the movements - and functions - of hand after repair. Most of the studies have evaluated adhesions following laceration repairs. The crush-type injury is the most common type after lacerations, and adhesions can be seen more often than lacerations due to irregular and extensive injury. Also, it is not always possible to repair a tendon properly following a crush-type injury.

Clamping with an Allis, a standard arterial or mosquito clamp constitutes most of the crush injury models. ${ }^{[20-23]}$ Most of these models do not have a standardization method for applied force with the clamp. ${ }^{[20-22]}$ The definitions about the surface and the application area of the clamps are missing. ${ }^{[20-23]}$ Also, the contradiction of reproducibility is the major obstacle in these models. In preliminary work, we have seen the rupture of tendons similar to laceration without using the maximum clamping, opposite to most of the studies. ${ }^{[20-22]}$ Unlike this situation, a crush injury usually develops with a contusion of tendon fibers due to pressure in our daily practice. ${ }^{[15,24]}$ Therefore, we have designed a different model to simulate the crush injury, and using a different model is the limitation of our study. Despite the limitation of using a different model, development of adhesions in the control group and differences between other groups were supportive for the success of this model.

Adhesions occur during the healing process. Tendon healing was thought to be caused by fibroblast infiltration from the surrounding connective tissue in the past. Therefore, adhesions have been thought to be a natural part of the healing process. However, follow-up studies showed that tenocytes could be fed from the synovial fluid, and the tendon has a selfhealing capacity without fibroblast infiltration. ${ }^{[2,25]}$ The fibroblast proliferation and development of the healing tissue from the extrinsic cellular activity is the cause of adhesion. Inhibition of the extrinsic cellular activity should be the main goal in preventing adhesions. Biological and synthetic solid barriers have been tested to prevent adhesions in recent years. ${ }^{[4-14]}$
The gel form of hyaluronic acid has been tested for peritendinous adhesions following repair of lacerations, and it was found to be effective before. In this present study Hyalobarrier gel was applied in Groups 2 and 4. Although it has been found to be effective in preventing adhesions after repair of tendon fibers in Group $4(p<0.05)$, it was ineffective in Group 2. Group 2 had similar results with the control group. Seprafilm has been evaluated in several studies for peritendinous adhesions following repair of laceration. Seprafilm has been applied in Groups 3 and 5 in our study. Unlike Group 2, Group 3 had fewer adhesions than the control group at the macroscopic examination $(p<0.05)$. Also, Group 5 had fewer adhesions than Groups I, 2, and 3 at macroscopic examination $(p<0.05)$. The use of Seprafilm in the crush-type injury resulted with a fewer adhesions at the macroscopic examination. The repair of tendon fibers with a stitch in Groups 4 and 5 reduced adhesions in both the macroscopic and histopathological examination. The penetration of hyaluronic acid gel between the crushed tendon fibers could act as a physical barrier against healing; this might be the possible mechanism in Group 2. Also, a lower number of fibroblasts, a better formation, and a higher density of collagen fibers in groups with repair of tendon fibers was supportive of this idea. Tendon fibers may not always be sutured properly following a crushtype injury. Therefore, a barrier should be effective when it is not possible to repair tendon fibers. Seprafilm met these criteria against the adhesion formation in our present study. Separating the crushed tendon and connective tissues until the inflammatory response diminishes might be the possible mechanism as seen in the abdomen. ${ }^{[16,17]}$

In conclusion, Seprafilm was found to be effective to prevent peritendinous adhesions following a crush-type injury, with or without repair of the tendon fibers. In contrast Hyalobarrier gel was found to be effective only following repair of tendon fibers.

Conflict of interest: None declared. 


\section{REFERENCES}

1. Gelberman RH, Vande Berg JS, Lundborg GN, Akeson WH. Flexor tendon healing and restoration of the gliding surface. An ultrastructural study in dogs. J Bone Joint Surg Am 1983;65:70-80. [CrossRef]

2. Manske PR. Flexor tendon healing. J Hand Surg Br 1988;13:237-45.

3. Chow JA, Thomes LJ, Dovelle S, Milnor WH, Seyfer AE, Smith AC. A combined regimen of controlled motion following flexor tendon repair in "no man's land". Plast Reconstr Surg 1987;79:447-55. [CrossRef]

4. Yilmaz E, Avci M, Bulut M, Kelestimur H, Karakurt L, Ozercan I. The effect of seprafilm on adhesion formation and tendon healing after flexor tendon repair in chicken. Orthopedics 2010;33:164-70. [CrossRef]

5. Menderes A, Mola F, Tayfur V, Vayvada H, Barutçu A. Prevention of peritendinous adhesions following flexor tendon injury with seprafilm. Ann Plast Surg 2004;53:560-4. [CrossRef]

6. Karakurum G, Buyukbebeci O, Kalender M, Gulec A. Seprafilm interposition for preventing adhesion formation after tenolysis. An experimental study on the chicken flexor tendons. J Surg Res 2003;113:195-200.

7. Liu Y, Skardal A, Shu XZ, Prestwich GD. Prevention of peritendinous adhesions using a hyaluronan-derived hydrogel film following partialthickness flexor tendon injury. J Orthop Res 2008;26:562-9. [CrossRef]

8. Işik $S$, Oztürk $S$, Gürses $S$, Yetmez $M$, Güler MM, Selmanpakoğlu $\mathrm{N}$, et al. Prevention of restrictive adhesions in primary tendon repair by HA membrane: experimental research in chickens. Br J Plast Surg 1999;52:373-9. [CrossRef]

9. Kulick MI, Smith S, Hadler K. Oral ibuprofen: evaluation of its effect on peritendinous adhesions and the breaking strength of a tenorrhaphy. J Hand Surg Am 1986;11:110-20. [CrossRef]

10. Kapetanos G. The effect of the local corticosteroids on the healing and biomechanical properties of the partially injured tendon. Clin Orthop Relat Res 1982;170-9. [CrossRef]

11. Stark HH, Boyes JH, Johnson L, Ashworth CR. The use of paratenon, polyethylene film, or silastic sheeting to prevent restricting adhesions to tendons in the hand. J Bone Joint Surg Am 1977;59:908-13. [CrossRef]

12. Ketchum LD. Effects of triamcinolone on tendon healing and function. A laboratory study. Plast Reconstr Surg 1971;47:471-82. [CrossRef]

13. Dabak TK, Sertkaya O, Acar N, Donmez BO, Ustunel I. The Effect of
Phospholipids (Surfactant) on Adhesion and Biomechanical Properties of Tendon: A Rat Achilles Tendon Repair Model. Biomed Res Int 2015;2015:689314. [CrossRef]

14. Li J, Feng X, Liu B, Yu Y, Sun L, Liu T, et al. Polymer materials for prevention of postoperative adhesion. Acta Biomater 2017;61:21-40. [CrossRef]

15. Sorock GS1, Lombardi DA, Hauser RB, Eisen EA, Herrick RF, Mittleman MA. Acute traumatic occupational hand injuries: type, location, and severity. J Occup Environ Med 2002;44:345-51. [CrossRef]

16. Kaptanoglu L, Kucuk HF, Yegenoglu A, Uzun H, Eser M, Mentes CV, et al. Effects of seprafilm and heparin in combination on intra-abdominal adhesions. Eur Surg Res 2008;41:203-7. [CrossRef]

17. Kurt N, Sıkar HE, Kaptanoğlu L, Küçük HF. Separate and synergistic effects of taurolidine and icodextrin in intra-abdominal adhesion prevention. Ulus Travma Acil Cerrahi Derg 2017;23:377-82.

18. Kaneko Y, Hirata Y, Achiwa I, Morishita H, Soto H, Kobayahsi J. Adhesion barrier reduces postoperative adhesions after cardiac surgery. Asian Cardiovasc Thorac Ann 2012;20:257-62. [CrossRef]

19. Tang JB, Ishii S, Usui M, Aoki M. Dorsal and circumferential sheath reconstructions for flexor sheath defect with concomitant bony injury. J Hand Surg Am 1994;19:61-9. [CrossRef]

20. Carvalho Pde T, Silva IS, Reis FA, Belchior AC, Aydos RD, Facco GG, et al. Histological study of tendon healing in malnourished Wistar rats treated with ultrasound therapy. Acta Cir Bras 2006;21 Suppl 4:13-7.

21. Aiyegbusi AI, Duru FI, Anunobi CC, Noronha CC, Okanlawon AO. Bromelain in the early phase of healing in acute crush Achilles tendon injury. Phytother Res 2011;25:49-52. [CrossRef]

22. Rajabi H, Sheikhani Shahin H, Norouzian M, Mehrabani D, Dehghani Nazhvani S. The Healing Effects of Aquatic Activities and Allogenic Injection of Platelet-Rich Plasma (PRP) on Injuries of Achilles Tendon in Experimental Rat. World J Plast Surg 2015;4:66-73.

23. McCombe D, Kubicki M, Witschi C, Williams J, Thompson EW. A collagen prolyl 4-hydroxylase inhibitor reduces adhesions after tendon injury. Clin Orthop Relat Res 2006;451:251-6. [CrossRef]

24. Goodman AD, Got CJ, Weiss AC. Crush Injuries of the Hand. J Hand Surg Am 2017;42:456-63. [CrossRef]

25. Lundborg G, Rank F. Experimental intrinsic healing of flexor tendons based upon synovial fluid nutrition. J Hand Surg Am 1978;3:21-31.

\section{DENEYSEL ÇALIŞMA - ÖZET}

\section{Sıçan modelinde ezilme tipi yaralanma sonrasında gelişen tendon yapışıklıklarının önlenmesinde Hyalobarrier Gel ve Seprafilm'in etkinliği \\ Dr. Emel Yurdakul Sıkar, ${ }^{1}$ Dr. Hasan Ediz Sıkar, ${ }^{2}$ Dr. Hüsamettin Top, ${ }^{3}$ Dr. Ahmet Cemal Aygıt ${ }^{1}$}

${ }^{1}$ Bağcılar Eğitim ve Araştırma Hastanesi, Plastik Rekonstrüktif ve Estetik Cerrahi Kliniği, İstanbul

${ }^{2}$ Kartal Dr. Lütfi Kırdar Eğitim ve Araştırma Hastanesi, Genel Cerrahi Kliniği, İstanbul

${ }^{3}$ Trakya Üniversitesi Tıp Fakültesi, Plastik Rekonstrüktif ve Estetik Cerrahi Anabilim Dalı, Edirne

AMAÇ: Çalışmamızda Hyalobarrier Gel ve Seprafilm'in ezilme tipi yaralanma sonrasında tendon yapışıklıklarının önlenmesi üzerindeki etkisini değerlendirmeyi amaçladık.

GEREÇ VE YÖNTEM: Yirmi beş adet 230-270 gram aralığında ve yedi-dokuz aylık dişi sıçanlar beş grup olarak randomize edildi. Grup I: Kontrol grubu, Grup 2: Hyalobarrier Gel grubu, Grup 3: Seprafilm grubu, Grup 4: Tendon onarımı ve Hyalobarrier Gel grubu, Grup 5: Tendon onarımı ve Seprafilm grubu olarak adlandırıldı. Her deney hayvanının iki gastroknemius kası tendonu olmak üzere toplamda 50 tendon kullanıldı. Deney hayvanları yüksek doz anestezi uygulamasıyla operasyon sonrası 40. günde sakrifiye edildiler. Yapışıklıkların makroskopik değerlendirilmesi iki kör araştırmacı tarafından Tang'ın yapışıklık dereceleme sistemiyle sınıflandırıldı. Histopatolojik değerlendirme için fibroblast sayıları, kollajen yoğunluğu ve yapısı değerlendirmeye alındı.

BULGULAR: Grup 2'de ciddi yapışıklık saptanmadı; Grup 3, 4 ve 5'te orta ve ciddi yapışılık saptanmadı. Grup 2 ve kontrol grubu arasında istatistiksel açıdan anlamlı fark bulunmadı ( $p=0.737)$. Grup 3, 4 ve 5; Grup I ve 2'den daha az yapışıklığa sahipti $(p<0.05)$. Grup 4 ve 5 sırasıyla Grup 2 ve 3 'ten daha az yapışıklığa sahipti $(p<0.05)$. Grup 3 ve 4 arasında istatistiksel açıdan anlamlı fark bulunmadı $(p=0.342)$. Histopatolojik bulgular da makroskopik bulgulara paraleldi.

TARTIŞMA: Seprafilm, ezilme tipi yaralanmayı takiben tendon yapışıkıılarını önlemede, tendon tamiri yapılan ve yapılmayan her iki grupta etkili bulundu. Buna karşılık Hyalobarrier Gel'in sadece tendon tamiri yapılan grupta yapışıklığı önlemede etkili olduğu saptandı.

Anahtar sözcükler: tendon yaralanmaları, cerrahi yapışıklıklar, seprafilm, hyalüronik asit

Ulus Travma Acil Cerrahi Derg 20।9;25(2):93-98 doi: 10.5505/tites.20।8.54007 